\title{
The Russian Government and Gazprom
}

\section{A Brief Economic Analysis of Russia in the post-Soviet Years:}

Following the collapse of the Soviet Union, the newly-formed Russian Federation faced a considerable economic downturn. During the post-Soviet economic collapse spanning from 1991 to 1998, Russian gross domestic product (GDP) fell from $\$ 509,381,640,192$ to $\$ 270,953,119,744$ (current US dollars). ${ }^{1}$ These figures represent a decline of $\$ 238,428,520,448$ or approximately $46.8 \%$ of the total GDP. This proverbial collapse of the Russian economy was largely due to changing incentives within the Russian market as it evolved from communism to capitalism. Further economic troubles ensued in 1998, spurred by a global recession resulting from the Asian financial crises of 1997. This fallout translated across economic markets; economies relying on the export of raw materials such as oil and natural gas were particularly affected as the price of oil reached a low of $\$ 8$ per barrel.

The financial collapse that gripped Russia in the 1990s was the result of multiple factors. Preceding the impact of the Asian economic woes, Russia only had one year of economic growth: 1997. Beginning in 1999, following a multinational effort to stimulate the Russian economy, Russia has enjoyed a period of economic growth that finally stabilized underVladimir Putin's administration at levels between $5 \%$ and $7 \%$ per year. This article seeks to correlate economic and social policy data, particularly focusing on the growth of Gazprom since 1998 and the Putin administration's restrictive media policy as it affects freedom of expression. We argue that the Russian government's restriction of media and the nationalization of Gazprom, a key element of Russian economic growth policy, are not mutually exclusive. The purpose of this paper is not to judge underlying oligarchic tendencies and the restriction of social policy as they augment the growth of the Russian economy, but rather to prove the existence of these trends using data acquired following the collapse of the Soviet Union.

\section{The Rise of Gazprom}

In his 2004 annual address to the Federal Assembly of the Russian Federation, Putin stated that doubling the GDP of Russia was a national goal over the course of the next decade:

\begin{abstract}
"Whether or not we can become a society of truly free people - free both economically and politically - depends only on us. Reaching our priority national goals depends only on us. These goals are well-known: doubling our gross domestic product over the next decade..."
\end{abstract}

By 2004, Russia's GDP growth rate had already stabilized at a healthy $5-7 \%$, but by 2007 the GDP had almost doubled from 590.71 billion USD in 2004 to 1.04 trillion USD. ${ }^{2}$ This abrupt improvement in economic performance contrasts starkly with the policy consensus following Putin's speech. In 2004, Ksenia Yudaeva of the Carnegie Endowment for International Peace noted that Putin's ambition for Russia's GDP was "a goal met with considerable skepticism by most economists." ${ }^{3}$ In the years between 2004 and 2007 there must have been a significant driving force behind Russia's surprising economic performance. We 
contend that Gazprom, an oil and gas giant now controlled by the Russian state, is partly responsible for this significant economic turnaround as measured by the correlations between Gazprom's economic performance and the performance of the Russian economy abound. The energy conglomerate provides almost $25 \%$ of the Russian government's tax receipts, and as of 2006 accounted for $9.6 \%$ of Russia's GDP. ${ }^{4}$

Gazprom has been subject to scrutiny almost from its inception. The Financial Times notes that the company was "[c]reated from the Soviet ministry of gas [and] has retained many features of a centrally planned economy," and the Organization for Economic Cooperation and Development asserts that "it can at times be difficult even to identify where the state budget ends and Gazprom's begins." ${ }^{\prime 5}$ Despite these undercurrents of suspicion, Gazprom underscored its intentions to privatize by offering Depositary Shares on a London exchange in addition to issuing stock on the Russian market. However, a series of events following Putin's election tipped Gazprom's future development back into the hands of the Russian government.

In 2001, after a series of scandals involving unpaid taxes, Gazprom's board of directors appointed Alexei Miller, a former Putin aide, as CEO. Recently, Miller has asserted that, "Specifically due to a prompt development of Gazprom's business in recent years we have probably a keener sense than our colleagues and partners of the disaccord between the existing 'rules of the game' in the energy sector and present-day challenges facing the global economy." ${ }^{\prime 6}$ Gazprom's growth, which we find to be facilitated in part by collusion with the Russian government, provides evidence that Miller's "present-day challenges" necessitate a serious change in the "rules of the game."

\section{Recent Developments in the Russian Oligarchy}

The year 2004 saw the disintegration of Yukos, a privatized Russian petroleum company. The abrupt collapse resulted from a political dispute in which the company's CEO backed an opposition political party, a move that triggered a sudden torrent of taxes to drive Yukos into bankruptcy. Shortly thereafter, Gazpromand Rosneftegaz, a Russian state-controlled petroleum conglomerate, absorbed the company's assets. ${ }^{7}$ In 2005, the most striking evidence of oligarchic tendency in the Russian government manifested itself through the purchase of $10.74 \%$ of Gazprom by Rosneft, also a state-owned petrochemical company. ${ }^{8}$ This purchase brought the Russian state's ownership of Gazprom to its current $50.002 \%$ majority stake. In exchange, the company liberalized foreign ownership rules for the remaining half of its shares. ${ }^{9}$

Gazprom proceeded to purchase Sibneft, a Russian oil company, as well as a significant portion of former Yukos assets and interests. ${ }^{10}$ The partial takeover of Royal Dutch Shell's Sakhalin-Il project in 2006 followed in response to Russian officials' revocation of Shell's environmental permit. ${ }^{11}$ Combined, these transactions created a swell of foreign interest in Gazprom that resulted in an extreme increase in valuation between 2004 and 2006. Its market capitalization soared from 54.24 billion USD in 2004 to 270 billion USD by the end of 2006. ${ }^{12}$ The combination of these developments underscores the extensive control that the Russian state exerts over its petrochemical industry. Noting Gazprom's significant contribution to the Russian GDP, it can be understood that its performance and its renationalization were crucial to Putin's execution of his stated goals.

\section{Russia and the Media}

According to a 2005 US State Department Report on Human Rights, the Russian government owns a majority share in Channel One, the largest Russian television channels, and directly owns the television station Rossiya, the second largest Russian television channel. ${ }^{13}$ In addition, through its holdings in Gazprom, the Russian 
government owns a majority share of Independent Television (NTV), Russia's third largest television channel. Masha Lipman of the Carnegie Endowment notes that one quarter of all Russians receive only the top two channels, and that Channel One is included in a list of assets strategic to the Kremlin. ${ }^{14}$ It appears that government control has spread to print media as well. According to the same report by the Carnegie Endowment, the state owns $20 \%$ of all national media outlets and $80 \%$ of all regional media outlets.

Raf Sharikov, former editor of the eminent Russian newspaper Izvestiya, experienced the government crackdown on media firsthand. According to an interview with the British Broadcasting Corporation (BBC), Sharikov submitted a forced resignation shortly after Izvestiya printed a story regarding the Beslan School siege questioning official casualty figures. ${ }^{15}$ Allegedly, Izvestiya received multiple phone calls from prominent figures within the Kremlin, including one from the president's spokesperson, calling "for blood" for challenging state figures. Rather than see his team of journalists fired (as was the case at NTV for refusing pro-government changes), Sharikov resigned. This assertion of governmental control occurred in 2004. In June of 2005, Izvestiya came under full control of the Russian government after being acquired by Gazprom's media division.

The amount of influence that the Russian government and state-controlled corporations exert on the media could potentially lead to limitations on the ability of Russian citizens to access critical information. Referring to a news article in which a gang came under arrest for slaying 40 people in an urban district, Raf Sharikov explains, "The news told me they were arrested and punished. But I didn't hear, for a year before that, stories about this gang terrorising the population. That's the manner of the news presented." In this example, the governmentinfluenced media only reported the positive situation: the gang's arrest. Other examples of government influence within the Russian media exist within Putin's own press corps. The Russian president travels with his own handpicked press pool. This creates an illusion of transparency between the government and the people. By having hand-selected members of a press corps at its disposal, the government is effectively filtering information flow through the Russian media. Putin understands the efficacy of using the Russian media to spread consensus among the Russian people and he uses this strategy well.

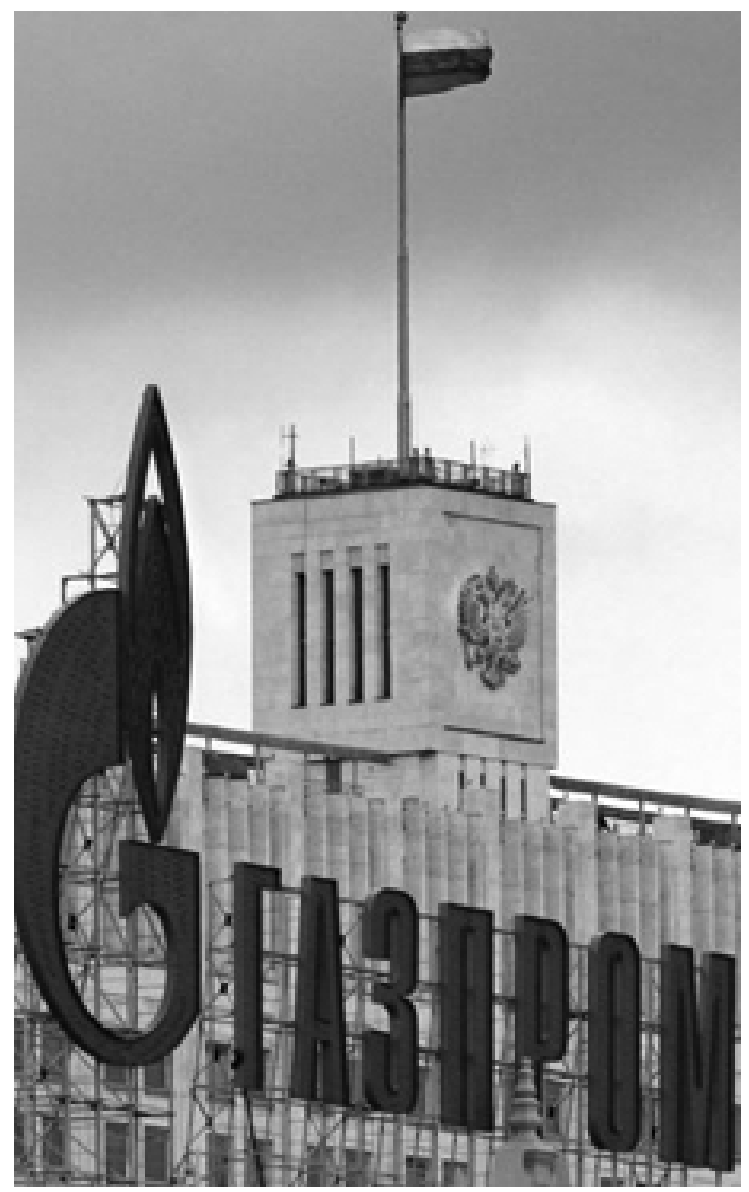

\section{Correlation in the Data}

The common factor between the Russian media and companies such as Gazprom is an attitude of state intervention in the public domain. Noting the percentage of GDP that Gazprom contributes to the 
Russian economy, it is within Russian interest to control information regarding the economy and thereby elicit economic growth in Russia. The means of doing so is available. The oligarchic structure of the Russian economy is evolving as the government assumes the role of master oligarch in the Russian energy trade as well as the Russian media. Given that the state-controlled Russian media goes to great lengths to censor the negative aspects of events such as gang slayings, we have reason to believe that this media establishment withholds or ignores information regarding negative aspects of corporate growth within Russia.

In the early days of post-Soviet Russia there was much ado over the enumeration of the rights of the Russian population. The new Russian constitution sought to concretely guarantee a dimension of personal and national freedom that was absent from the Soviet Union. Under Putin's program of economic growth, a disparity has emerged between this form of expansion and the rights of the Russian people, as illustrated by violations of at least two particular sections in the constitution.

The Russian government is refuting that the constitution meant to dictate how it should govern, particularly by contradicting the provisions of articles 29 and 34. Quoting a section of Article 29, "Everyone shall be guaranteed freedom of thought and speech...Propaganda shall also be prohibited...The freedom of the mass media shall be guaranteed. Censorship shall be prohibited." ${ }^{16}$ Arguably while this freedom still exists due to a lack of government ownership of all media outlets, there is a conflict of interest at foot. Notwithstanding the lack of outright government ownership, the Russian government controls the top three television stations in Russia, handpicks the Kremlin press corps, and exerts pressure on non-government owned media. Article 34 states, "1. Everyone shall have the right to use freely his (her) abilities and property for entrepreneurial and other economic activity not prohibited by law. 2. Economic activity aimed at monopolization and unfair competition shall not be permitted."17 Gazprom itself is an example of a monopoly that has grown with direct support from the government. While it is easy to see how the overall Russian economy may benefit from state-controlled corporations and media control, it is arguable that state control, by allowing Russia to become better off economically, has cost the Russian people the validity of their constitution.

By directly shedding the constraint of article 34 and subversively maneuvering around article 29 of the constitution, the Russian government endangers its legitimacy. Despite this, the majority of Russian people are enjoying greater prosperity than ever before. This must lead us to question if there is a price that people should put on their rights. It is morally ambiguous to say that one argument or another is correct in this case. The state does not own all media outlets and does not control all corporations. Those that the state has in its hand, however, are profiting quite well, and it appears that the Russian government has taken action to allow corporations such as Gazprom to monopolize entire industries. The Russian government directly benefits from good performances by firms like Gazprom on both national and international markets. This translates to taxes and dividends for the Russian government as well as increased economic activity within the country. It is within the best interest of the Russian government to combine media control with industrial monopolization to elicit further economic growth, and it is our hope that the international community becomes more aware of this correlation. 


\section{Endnotes}

${ }^{1}$ World Development Indicators. World Bank. [Online Resource]. Retrieved October 27th 2007 , from http://www.worldbank.org

${ }^{2}$ World Economic Outlook Database. IMF. [Online Resource]. Retrieved October 27 ${ }^{\text {th }}, 2007$, http://www.imf.org/external/pubs/ft/weo/2007/02/ weodata/index.aspx

${ }^{3}$ President Putin`s Address to the Parliament: a Statist-Liberal Mixture. Ksenia Yudaeva (Carnegie Endowment for International Peace). [Online Resource]. Retrieved October 27 ${ }^{\text {th }}, 2007$, http://www.carnegie.ru/en/print/70671-print.htm

${ }^{4}$ Gazprom in Figures 2000-2006. Gazprom. [Online Resource]. Retrieved November 16 ${ }^{\text {th }}, 2007$, http://www.gazprom.com/documents/Stat Report Eng.pdf

${ }^{5}$ Gazprom Acts as Lever in Putin's Power Play. Hermitage Capital Management. [Online Resource]. Retrieved November 16 ${ }^{\text {th }}$, 2007, from http:// hermitagefund.com/index.pl/news/article.html?id=788

${ }^{6}$ The Process of Gazprom's Conversion from the "National Champion" into a Global Energy Business Leader has been Completed.Gazprom. [Online Resource]. Retrieved November $16^{\text {th }}, 2007$, from http://www.gazprom.ru/eng/articles/article24271.shtml

${ }^{7}$ Gazprom, Rosneft: Divided in Unity. International Relations and Security Network (ISN). [Online Resource]. Retrieved November 16 ${ }^{\text {th }}, 2007$, from http://www.isn.ethz.ch/news/sw/details.cfm?ID=16607

${ }^{8}$ Gazprom in Figures 2000-2006. Gazprom. [Online Resource]. Retrieved November 16 ${ }^{\text {th }}, 2007$, http://www.gazprom.com/documents/Stat_Report Eng.pdf

${ }^{9}$ Gazprom Opens Doors to Foreigners. BBC. [Online Resource]. Retrieved November 16 ${ }^{\text {th }}, 2007$, from http://news.bbc.co.uk/2/hi/business/4618163. $\underline{\text { stm }}$

${ }^{10}$ Gazprom Scoops up Sibneft for $\$ 13$ Billion. Johnson's Russia List. [Online Resource]. Retrieved November 16 ${ }^{\text {th }}, 2007$, from (http://www.cdi.org/russia/ johnson/9258-5.cfm)

${ }^{11}$ Gazprom, Shell, Mitsui, Mitsubishi sign Sakhalin II protocol. Mitsui \& Co., Ltd.. [Online Resource]. Retrieved November 16 ${ }^{\text {th }}$, 2007, from http://www. mitsui.co.jp/en/release/2006/1176280 1210.html)

${ }^{12}$ Gazprom in Figures 2000-2006. Gazprom. [Online Resource]. Retrieved November 16, th 2007, http://www.gazprom.com/documents/Stat Report Eng.pdf

${ }^{13}$ Russia, Country Reports on Human Rights Practices 2005. U.S. Department of State. [Online Resource]. Retrieved November $16^{\text {th }}$, 2007, from http://www.state.gov/g/drl/rls/hrrpt/2005/61671.htm

${ }^{14}$ Russia's Overmanaged Democracy: What the Kremlin Has substituted for Emasculated Institutions. Carnegie Endowment for International Peace. [Online Resource]. Retrieved November $16^{\text {th }}, 2007$, from

(http://www.carnegieendowment.org/events/index.cfm?fa=eventDetail\&id=982\&\&prog=zru

${ }^{15}$ Viewpoint: 'Soviet' grip on Russian media. BBC. [Online Resource]. Retrieved November 16 ${ }^{\text {th }}, 2007$, from (http://news.bbc.co.uk/2/hi/europe/4043389. stm)

${ }^{16}$ The Constitution of Russia. President of Russia Official Web Portal. [Online Resource]. Retrieved November $16^{\text {th }}, 2007$, from (http://www.kremlin.ru/eng/articles/ConstEng2.shtml)

${ }^{17}$ The Constitution of Russia. President of Russia Official Web Portal. [Online Resource]. Retrieved November $16^{\text {th }}, 2007$, from

(http://www.kremlin.ru/eng/articles/ConstEng2.shtm 